\title{
PELATIHAN PENGOPERASIAN DAN PERAWATAN MESIN PRODUKSI DENGAN KENDALI ELEKTRONIKA UNTUK PENGAJAR PROGRAM STUDI TEKNIK LISTRIK INDUSTRI DI SMK TUREN - KAB. MALANG
}

\author{
M.Mieftah $^{1}$, M.Manaf ${ }^{2}$, Awan,S.S ${ }^{3}$ Rachamad.S ${ }^{4}$,Anang,DN ${ }^{5}$ \\ Jurusan Teknik Elektro, Program Studi Teknik Listrik, Politeknik Negeri Malang \\ e-mail: Mieftah@yahoo.com ${ }^{2}$
}

\begin{abstract}
Training on Operation and Maintenance of Production Machines with Electronic Control for Instructors in the Industrial Electrical Engineering Study Program at SMK Turen - Kab. Malang, provides additional teaching and motivation for teachers of Electrical Engineering study programs at SMK Turen practicing Operation and Maintenance of Production Machines with Electronic Control. Besides that, it can also increase additional skills for teachers of the electrical engineering study program at the current Turen Vocational School
\end{abstract}

Keywords: Production Machines, Electronic Control

\section{PENDAHULUAN}

\subsection{Latar Belakang}

Kondisi lingkungan di SMK Turen - Kabupaten Malang . khususnya Program Studi Teknik instalasi yang sedang mengembangkan modul praktek guna mempersiapkan dan menambah jumlah modul untuk anak didiknya khususnya siswa - siswa SMK Turen. . Untuk sasat ini yang keinginan untuk mengembangkan modul - modul praktek khususnya yang berkaitan dengan Pelatihan Pengoperasian dan Perawatan Mesin Produksi dengan Kendali Elektronika kurang dapat dipahami oleh pengajar - pengajar dalam bidang praktek,sehingga menghambat kemajuan praktek bagi siswa SMK Turen,apalagi khususnya dapat dirasakan oleh siswa kelas tiga yang menghadapi ujian kompetensi personel.

Di SMK Turen. terdapat 10 pengajar pada program studi teknik Instalasi Tenaga Listrik dan sebagian besar merupakan pengajar praktek, Mereka berpendidikan S1 dari sarjana pendidikan dan yang S1 bidang teknik hanya sebagian

Berdasarkan kedua kondisi di atas, yaitu kondisi lingkungan dan kondisi potensi sumber daya manusia para pengajari, maka dapat diambil suatu peluang untuk dapat melaksanakan pengabdian pada masyarakat. Pengabdian pada masyarakat tersebut berbentuk Pelatihan Pengoperasian dan Perawatan Mesin Produksi dengan Kendali Elektronika kepada pengajar program studi teknik listrik SMK Turen, sehingga nantinya dapat menambah keterampilan para pengajar dalam bidang instalasi listrik dan praktek kendali. Kemudian diharapkan mereka dapat berupaya untuk melaksanakan Pelatihan Pengoperasian dan Perawatan Mesin Produksi dengan Kendali Elektronika untuk Pengajar Program Studi Teknik listrik SMK Turen, sehingga dapat pelaksanaan praktek dan uji kompetensi sesuai kurikulum SMK yang berlaku.

\subsection{Tujuan Kegiatan}

1. Memberikan tambahan pengetahuan dan pengoperasian dan Perawatan Mesin Produksi dengan Kendali Elektronika kepada pengajar program studi teknik listrik SMK Turen, Memotivasi para pengajar untuk pengembangan sasarana praktek guna memenuhi target kurikulum SMK yang berlaku

\section{TINJAUAN PUSTAKA}

Materi Pelatihan Pengoperasian dan Perawatan Mesin Produksi dengan Kendali Elektronika kepada pengajar program studi teknik listrik SMK Turen, merupakan modul bahan ajar praktikum yang mengoperasikan peralatan sesuai dengan identifikasi masing-masing fungsi dan pengoperasiannya. Diagram kerja dan sistim kelistrikan harus dipahami berdasarkan standar praktis. Penggunaan alat ukur dan pembacaannya harus sesuai dengan spesifikasi pabrikan. Pengoperasian Pelatihan Pengoperasian dan Perawatan Mesin Produksi dengan Kendali Elektronika kepada pengajar program studi teknik listrik SMK Turen, dioperasikan dengan urutan kerja. Mengatasi gangguan yang berkaitan dengan penyimpangan penunjukan alat ukur dan penyebab lainnya. Pelaporan yang dibuat dengan format dan prosedur yang ditetapkan.

Untuk menentukan sistem pengajaran praktek di program studi teknik listrik SMK Turen ., harus diketahui modul penunjang apa yang sesuai dengan kurikulum yang berlaku dan SDM pengajar yang ada dulu, guna memenuhi sasaran yang tepat .Oleh karena itu dengan pengetahuan dan keterampilan cara Pelatihan pengoperasian dan Perawatan Mesin Produksi dengan Kendali Elektronika kepada pengajar program studi teknik listrik SMK Turen,. , dikemudian hari menjadikan SMK tersebut semakin maju memenuhi kurikulum yang berlaku.

Dengan materi pelatihan memelihara dan Pelatihan Pengoperasian dan Perawatan Mesin Produksi dengan Kendali Elektronika kepada pengajar program studi teknik listrik SMK Turen, sangat cocok untuk penunjang Pelatihan tersebut pada era kurikulum SMK sekarang bukan lagi barang yang baru, melainkan sesuatu yang harus terpenuhi demi kemajuan dan pemenuhan kurikulum praktek di SMK tersebut

Komponen dan Prinsip Kerja SCR 
Pengembangan elektronika akhir-akhir ini maju dengan sangat pesat setelah ditemukan beberapa jenis rumpun Solid State diantaranya Transistor. Dioda, UJT, dll. Beberapa laboratorium elektronika berusah menemukan suatu jenis Solid State yang dapat dipergunakan untuk mengendalikan daya listrik sebagai pengganti tabung air raksa yang biasa dikenal dengan nama THYRATRON. Ternyata keinginan ini telah dicapai dengan ditemukannya apa yang disebut "THYRISTOR" Nama telah diambil dari gabungan Thyaratron dan Transistor. Pada tahun 1957 Thyristor telah direproduksi dan telah dipasarkan pula. Thyristor dibuat dari susunan bahan silicon dan sifatsifatnya yang hampir mirip dengan silicon rectifier juga dengan dioda 4 lapis. Keistimewaan dari Thyristor dibanding dengan silicon rectifier, adanya tambahan elektroda yang disebut Gate. Gate ini merupakan tempat dimana Thyristor dikendalikan (controlled) karena itu Thyristor juga disebut "Silicon Controlled Rectifier" disingkat menjadi SCR. Pada saat sekarang ini penggunaan SCR sangat luas karena SCR dapat mengendalikan arus listrik yang cukup besar dan dapat pula dipergunakan langsung untuk jaringan arus tukar (AC). Penggunaan yang nyata pada saat sekarang ini adalah untuk switching daya listrik yang besar yang dapat mengendalikan pengaturan beban putaran motor listrik, pengaturan alat pemanas listrik, pengatur lampu penerangan, relay dan alat-alat alarm yang sangat peka. Bahkan dalam industriindustri sekarang ini SCR digunakan sebagai sarana pelengkap automat yang menggantikan alat-alat yang sangat peka.

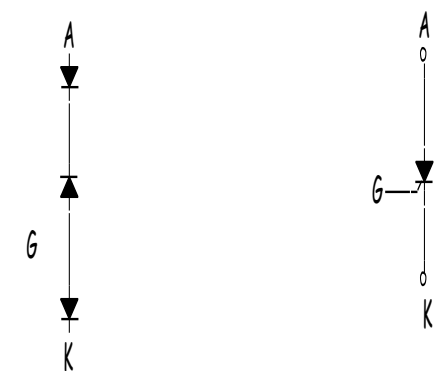

Gambar 2.1a. Susunan Fisis SCR Gambar 2.1b. Symbol SCR

\subsubsection{Sifat-Sifat SCR}

1) Dalam keadaan gate tidak diberikan picu (trigger), SCR tidak menghantrakan arus, istilahnya dalam keadaan demikian ini "OFF" atau "Blocked". Hal ini dapat dipersamakan (antara anoda dan katoda) dengan switch dalam keadaan terbuka.

2) Apabila tegangan picu (meskipun hanya sesaat) diberikan pada gate, maka SCR akan menghantar atau "ON". Jadi, SCR akan bekerja sebagai silicon dioda biasa yang dapat menghantar arus pada jurusan dari anoda ke katoda, akan tetapi "blocked" pada jurusan yang sebaliknya.

3) Sewaktu SCR telah "ON", kemudian secara mendadak tegangan positif pada gate kita putuskan, maka SCR tetap ON. Jelasnya untuk membuat SCR dapat ON cukup dengan memberikan tegangan positif dalam waktu yang pendek karena da;am pemakain tegangan (DC), SCR akan bekerja terus-menerus seperti halnya silicon rectifier biasa bahkan kita dapat melakukan pengendalian SCR dengan memberikan pulse positif pada gatenya.

4) Hubungan antara gate dan katoda pada SCR bersifat seperti dioda silicon, sehingga antara gate dan katoda berimpedansi rendah pada rah forward (conduct). Pengendalian tegangan gate dibutuhkan antara 1-2 volt saja dengan arus gate beberapa puluh miliampere, tegangan dan arus ini sudah cukup untuk membuat SCR yang berkemampuan menghantar arus sebesar beberapa puluh ampere (arus anoda-katoda).

5) Apabila SCR telag dalam keadaan ON, cara untuk meng-OFF kan kembali tak dapat dilakukan melalui gate, melainkan kita harus menurunkan besarnya arus anoda-katoda sampai batas dibawah nilai Ih "holding current" (nilai mendekati nol). Apabila sekarang SCR digunakan untuk keperluan arus tukar AC, kita tak mendapat kesulitan sebab setiap setengah periode positif akhir, tegangan arus AC akan menurun dan kemudian nol sahingga SCR secara otomtis OFF dengan sendirinya.

Sebagaimana telah dibahas sebelumnya, bahwa Thyristor merupakan kompenen break over, khususnya SCR dan triac adalah kompenen break over yang tinggi tegangan konduknya, tetapi dengan mengatur melalui sinyal picu yang diberikan pada gate, sehinggga dengan tegangan yang kecil komponen tsb dapat mengalirkan arus (konduk).

Di dalam rangkaian kenverter $\mathrm{AC}$, Thyristor merupakan komponen utama melalui pengontrolan lebar sudut konduk (conduction angle) atau sudut penundaan picu (firing delay angle). Rangkaian dasar SCR dan Triac beban dan sumber tegangan diperlihatkan pada gambar 1.3b. dan gambar $1.3 \mathrm{c}$. memperlihatkan sudut konduk SCR $120^{\circ}$ maka sudut picunya $60^{\circ}$ dan bila sudut konduknya $45^{\circ}$, sudut picunya $135^{\circ}$. Selanjutnya gambar 1.2e. memperlihatkan sudut konduk dan sudut picu.
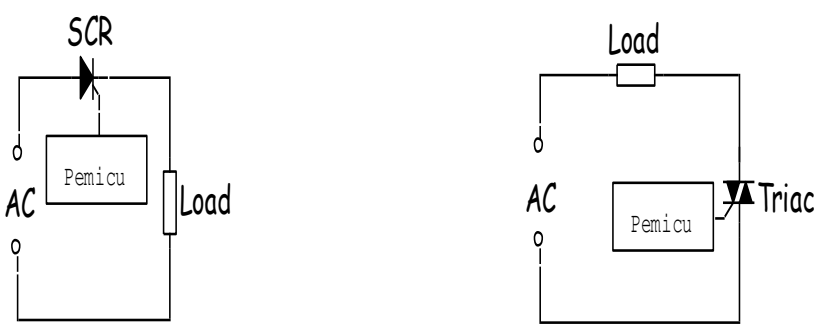

Gambar 2.3a. Rangkain Dasar Pengontrol dengan SCR dan Triac

\subsection{UNI JUNCTION TRANSISTOR (UJT)}


UJT disimbolkan sebagai gambar 2.1a. dan konsrtuksinya diperlihatkan pada gambar $2.1 \mathrm{~b}$. dimana sebatang bahan semikonduktor silicon didop ringan dengan unsur dari golongan 5 sehingga menjadi tipe $\mathrm{N}$. Ujung batang ini menjadi $\mathrm{B}_{1}$ dan $\mathrm{B}_{2}$ dengan nilai resistansi antara $\mathrm{B}_{1}$ dan $\mathrm{B}_{2}$ cukup besar kira-kira $10 \mathrm{~K} \Omega$.

Kira-kira ditengah-tengah batang $\mathrm{B}_{1}$ dan $\mathrm{B}_{2}$ diberikan dope agak berat dari unsur golongan 3 sehingga terbentuk tipe $\mathrm{P}$ yang berfungsi sebagai emitter (E).

Rangkian ekuivalen dari UJT yang sederhana dapat dilihat pada gambar 2.1c.

Antara emitter ke persambungan (junction) basis tampak sebagai sebuah PN dioda. Tahanan antara basis $R_{B B}$ dari batang silicon tipe $N$, merupakan dua buah resistor $\mathrm{R}_{\mathrm{B} 1}$ dan $\mathrm{R}_{\mathrm{B} 2}$.

Jika ada arus yang mengalir dari emitter ke basis 1 dan UJT akan "ON" dimana $\mathrm{R}_{\mathrm{B} 1}$ nilainya kan turun secara tajam.

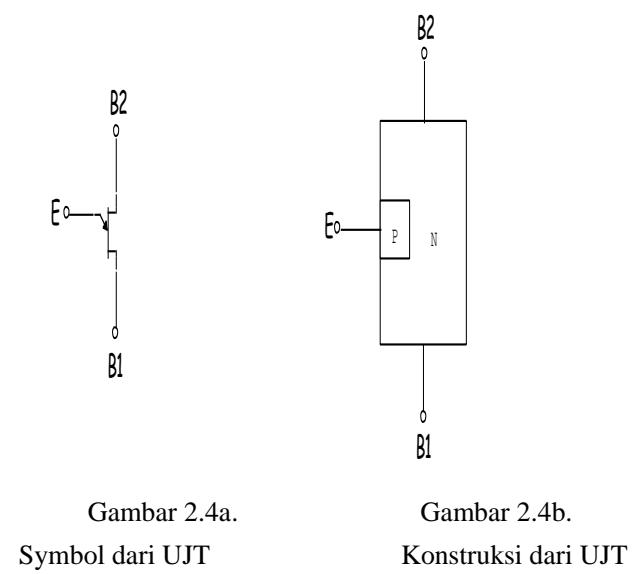

Nilai tahanan $R_{B 1}$ akan berubah-ubah tergantung dari besarnya arus emitter yang mengalir.

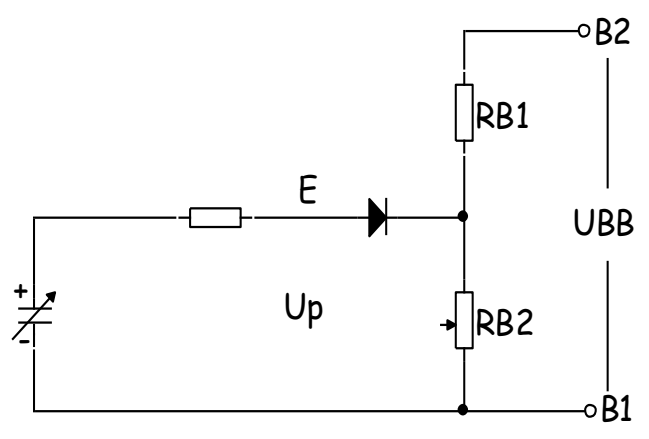

Gambar 2.5c. Rangkaian Ekuivalen dari UJT

Sejak terjadi penghantaran, $\mathrm{R}_{\mathrm{B} 1}$ merupakan fungsi dari arus emitter, variasi tahahan $R_{B 1}$ disebabkan oleh perubahan arus emitter dan dalam hal ini disebut sebagai "Conductivity Modulation".
Jika tidak terdapat aliran arus emitter $\mathrm{I}_{\mathrm{E}}$ tegangan $\mathrm{U}_{\mathrm{AB} 1}$ dari titik $\mathrm{A}$ ke $\mathrm{B}_{1}$ dapat ditulis sebagai berikut:

\section{UJT Sebagai Relaxation Oscilator}

Dalam gambar 2.2a. memperlihatkan UJT yang dihubungkan sebagai Relaxion Oscilator dimana rangkaian ini dapat membangkitkan bentuk gelombang tegangan $\mathrm{U}_{\mathrm{B} 1}$ yang dapat digunakan sebagai pemicu gate sebuah SCR.

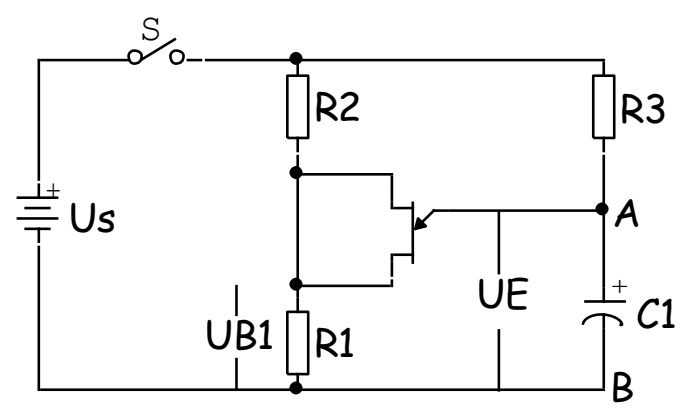

Gambar 2.2a. Relaxation Oscilator UJT

Gambar dibawah ini memperlihatkan contoh penggunaan Relaxion Oscilator dalam rangkaian pengontrol SCR.

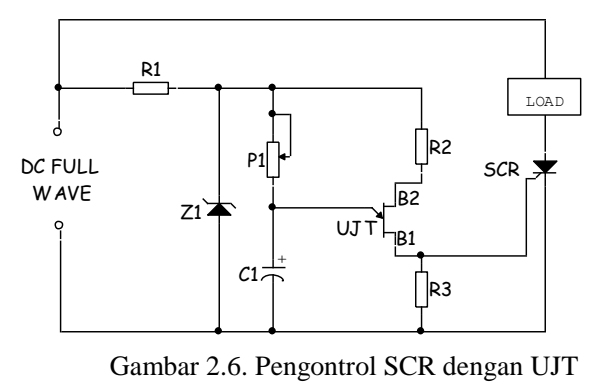

\subsection{Push Botton}

Push botton disebut juga saklar tekan atau tombol tekan. Bekerja pada saat tombol ditekan akan merubah kontak NO menjadi NC dan NC menjadi NO.

Berdasarkan jenis kontaknya terdiri dari: Single kontak dan Double kontak
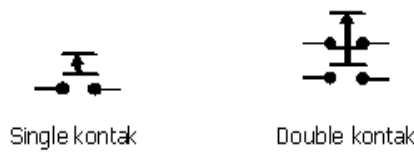

Gambar 5. Simbol tombol tekan 

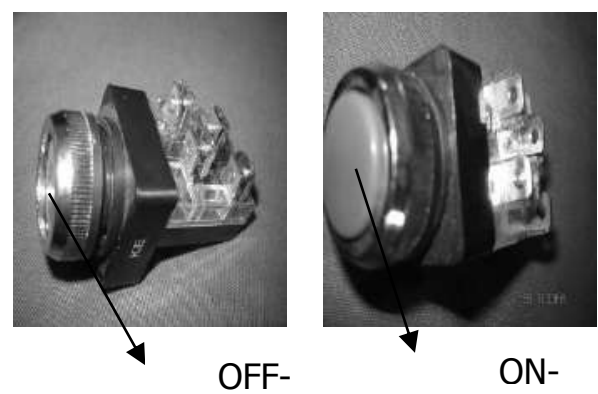

Gambar 6. Tombol Tekan

\subsection{Memahami Rangkaian Pengendali Pengalih Daya}

Pada Panel Pengalih daya terdapat rangkaian pengendali yang ditempelkan pada belakang pintu panel. Hal ini bertujuan untuk memudahkan operator di dalam memahami mengoperasian peralatan pengalih daya.

Di dunia industri banyak terdapat berbagai macam rangkaian pengendali seperti misalkan: Rangkaian Pengendali Direct On Line, Forward-reverse Motor, Sistim Pengasutan dan lain-lain.

Yang harus diperhatikan di dalam memahami rangkaian pengendali pengalih daya antara lain:

1. Mengetahui sumber energi yang digunakan

2. Memahami simbol-simbol kelistrikan

3. Mengenal komponen yang terpasang

4. Mengetahui cara kerja komponen

5. Mengetahui urutan penempatan komponen

6. Mengetahui Penggunaan Pengalih daya

7. Memahami cara kerja peralatan

8. Memahami cara kerja rangkaian pengendali

\section{MATERI DAN METODE}

\subsection{Khalayak Sasaran}

Pelatihan ini ditujukan untuk kepada pengajar program studi Teknik Instalasi Tenaga Listrik SMK Turen.

\subsection{Metode PKM}

Untuk menentukan metode PKM maka sistem pengajaran praktek di program pengabdian masyarakat ini, harus diketahui modul penunjang apa yang sesuai dengan kurikulum yang berlaku dan SDM pengajar yang ada dulu, guna memenuhi sasaran yang tepat. Oleh karena itu dengan pengetahuan dan keterampilan cara merancang, merencanakan Pelatihan Pengoperasian dan Perawatan Mesin Produksi dengan Kendali Elektronika untuk Pengajar Program Studi Teknik listrik SMK Turen, dan peraturan instalasi listrik yang sesui PUIL 2000 kepada pengajar program studi teknik listrik SMK Turen.

Dengan dibuatkan buku panduan teori dan praktek Pelatihan Pengoperasian dan Perawatan Mesin Produksi dengan Kendali Elektronika untuk Pengajar Program Studi Teknik listrik SMK Turen,sangat cocok untuk penunjang Pelatihan Pelatihan Pengoperasian dan Perawatan Mesin Produksi dengan Kendali Elektronika untuk Pengajar Program Studi Teknik listrik SMK Turen, sekarang bukan lagi barang yang baru, melainkan sesuatu yang harus terpenuhi demi kemajuan dan pemenuhan kebutuhan masyarakat mengenai pemanfaatan ketenagalistrikan tersebut.

Kegiatan Pelatihan Pengoperasian dan Perawatan Mesin Produksi dengan Kendali Elektronika untuk Pengajar Program Studi Teknik listrik SMK Turen,ini, dilaksanakan dengan metode langsung praktek, yaitu:

1. Pengenalan peralatan dan teori standar instalasi listrik sesuai PUIL 2000

2. Pengenalan Pelatihan Pengoperasian dan Perawatan Mesin Produksi dengan Kendali Elektronika,

3. Mesin Produksi dengan Kendali Elektronika,

Metode ini dipilih karena mengingat keterbatasan waktu, tenaga, dan dana yang tersedia.

\subsection{Rancangan Evaluasi}

Evaluasi diadakan pada hari kedua, yaitu di akhir acara, meliputi:

1. Demontrasi, presentasi dan wawancara langsung terhadap peserta pelatihan.Mesin Produksi dengan Kendali Elektronika,

2. Disamping itu untuk melihat secara nyata, hasil ketrampilan yang telah diajarkan kepada pengajar program studi teknik listrik SMK Turen. secara keseluruhan, akan dilakukan peninjauan langsung oleh tim pelaksana 15 hari kemudian

\section{PEMBAHASAN}

Berdasarkan metode yang diterapkan dalam pelaksanaan pengabdian kepada masyarakat ini, maka dapat dicapai hasil antara lain :

Metode materi, dan peragaan yang dilaksanakan dapat efektif mencapai tujuan yang diinginkan, jika dikaitkan dengan keterbatasan waktu pelaksanaan

1. Peserta Pelatihan Mesin Produksi dengan Kendali Elektronika,untuk Pengajar Program Studi Teknik Listrik di SMK Turen - Kabupaten Malang perserta pelatihan dapat melihat langsung peralatan yang dipasang.

2. Peserta pelatihan dapat terampil melakukan Mesin Produksi dengan Kendali Elektronika,secara sederhana dengan baik dan standart.

3. Peserta pelatihan dapat mengatasi sendiri, jika ada permasalahan atau kerusakan Mesin Produksi dengan Kendali Elektronika,

4. Peserta dapat menikmati secara langsung hasil dari praktek Mesin Produksi dengan Kendali Elektronika. 


\section{KESIMPULAN DAN IMPLIKASI}

\subsection{Kesimpulan}

Setelah menelaah segala sesuatu yang berhubungan dengan aktivitas Mesin Produksi dengan Kendali Elektronika,kepada untuk pengajar Pengajar Program Studi Teknik Listrik di SMK Turen, Kabupaten Malang , maka dapat diambil kesimpulan yaitu :

1. Membantu peserta dan memberikan tambahan ketrampilan Mesin Produksi dengan Kendali Elektronika,

2. Kepada pengajar Pengajar Program Studi Teknik Listrik di SMK Turen - Kabupaten Malang Memotivasi bagi para pengajar dan siswa untuk pengembangan praktek Mesin Produksi dengan Kendali Elektronika, di program studi Teknik tersebut.

3. Memperbanyak tambahan keterampilan kepada pengajar Pengajar Program Studi Teknik Listrik di SMK Turen.Dengan demikian kegiatan pengabdian kepada masyarakat ini mendapatkan antusias yang tinggi dari peserta pelatihan dan mereka mengharapkan adanya tindak lanjut program pengabdian kepada masyarakat berikutnya.

\subsection{Saran}

1. Perlu adanya tindak lanjut dari kegiatan ini, terutama dalam memberikan bimbingan dan dorongan kepada peserta pelatihan tentang manfaat dari Mesin Produksi dengan Kendali Elektronika,kepada untuk pengajar Pengajar Program Studi Teknik Listrik di SMK Turen Kabupaten Malang

2. Teknik Instalasi Tenaga Listrik di SMK Turen Kabupaten Malang

\section{DAFTAR PUSTAKA}

[1]. Badan Standarisasi Nasional. Persyaratan Umum Instalasi Listrik 2000

(PUIL

2000). Jakarta: Yayasan PUIL, 2000.

[2]. E. Setiawan, Ir. Instalasi Arus Kuat. Jakarta: PT Bina Cipta, 1986

[3]. Harten, Edi Setiawan. 1981. Instalasi Listrik Arus Kuat 1. Bina Cipta. Jakarta.

[4]. Harten, Edi Setiawan. 1981. Instalasi Listrik Arus Kuat 2. Bina Cipta. Jakarta

[5]. Kismet Fadillah. Instalasi Motor Listrik. Bandung: PT Angkasa, 1999

[6]. Perusahaan Listrik Negara. Teknologi Jaringan Distribusi. Jakarta: Pusat Pendidikan dan Latihan, 1986.

[7]. Sumaryono, Marsudi. Petunjuk Keselamatan Kerja. Jakarta: Departemen Pendidikan dan Kebudayaan, 1998. 